\title{
UTILIZATION OF MUĞLA FLY ASH AND QUARTZ DUST IN ENGINEERED CEMENTITIOUS COMPOSITES PRODUCTION AT HIGH VOLUMES
}

\author{
Süleyman Bahadır KESKİN*, Civil Engineering Department, Muğla Sıtkı Koçman Üniversitesi, Turkey, sbkeskin@mu.edu.tr \\ (D)https://orcid.org/0000-0002-2802-5379) \\ Olkan İlter TAȘ, Civil Engineering Department, Muğla Sıtkı Koçman Üniversitesi, Turkey, olkan.ilter.tas@gmail.com \\ (iDhttps://orcid.org/0000-0001-9668-6059) \\ Özlem KASAP KESKIN, Civil Engineering Department, Muğla Sıtkı Koçman Üniversitesi, Turkey, okasapkeskin@mu.edu.tr \\ (iDhttps://orcid.org/0000-0003-4475-2186) \\ Received: 10.01.2020, Accepted: 09.04.2020 \\ *Corresponding author \\ Research Article \\ DOI: $10.22531 /$ muglajsci.673036
}

\section{Abstract}

Concrete, because of its brittle nature, is very prone to cracking especially under induced tensile stresses. Those cracks make the material vulnerable to external influences. Water penetrating through the cracks yields various durability issues that shorten the service life of the concrete. However, contrary to ordinary concrete, in Engineered Cementitious Composites (ECC) formation of multiple and tight micro-cracks under loading yields to high ductility, energy absorption capacity and durability. Besides, these tiny cracks also exhibit self-healing properties with the help of a high amount of binding materials available in composite composition. Within the scope of this study, in the design of the ECC, two different mixtures with low and high fly ash amounts were produce. Furthermore, waste materials of the Muğla region which cause environmental pollution and have little or no commercial value were used in ECC production. Mechanical strength values and self-healing properties of the specimens were investigated at the scope of the study.

Keywords: Engineered Cementitious Composites (ECC), Fiber Reinforced High Performance Cementitious Composites, Waste Recycling, Self-Healing

\section{MUĞLA UÇUCU KÜLÜ VE KUVARS TOZUNUN TASARLANMIŞ ÇIMMENTOLU KOMPOZIT ÜRETIMINDE YÜKSEK HACIMDE KULLANILABİLIRLİĞİ}

\section{Özet}

Beton, gevrek yapısı nedeniyle, özellikle tetiklenmiş çekme gerilmeleri altında çatlamaya meyillidir. Bu çatlaklar malzemeyi dış etkenlere karşı savunmasız hale getirir. Çatlaklardan geçen su betonun ömrünü kısaltan çeşitli dayanıklılık sorunları doğurur. Ancak, normal betonun aksine, Tasarlanmış Çimentolu Kompozitlerde (TÇK), yükleme altında çok sayıda ve sıkı mikro çatlak oluşumu, yüksek süneklik, enerji yutma kapasitesi ve dayanıklılık sağlar. Ayrıca, bu küçük çatlaklar, bileşimde bulunan yüksek miktarda bağlayıcı malzeme yardımı ile kendi kendini iyileştirme özellikleri de sergiler. Bu çalışma kapsamında, ECC tasarımında, düşük ve yüksek uçucu kül miktarlarına sahip iki farklı karışım üretilmiștir. Buna ek olarak, Muğla bölgesinin çevre kirliliğine neden olan ve az veya hiç ticari değeri olamayan atık malzemeleri TÇK üretiminde kullanılmıștır. Çalışma kapsamında numunelerin mekanik dayanım değerleri ve kendi kendini iyileștirme özellikleri incelenmiștir.

Anahtar Kelimeler: Atık Geri Dönüşümü, Kendiliğinden İyileşme, Tasarlanmış Çimentolu Kompozitler, Yüksek Performansı Lif Donatılı Çimentolu Kompozitler

Cite

Keskin, S. B., Taş, O. İ., Kasap Keskin, Ö. (2020). “Utilization of Muğla Fly Ash and Quartz Dust in Engineered Cementitious Composites Production at High Volumes", Mugla Journal of Science and Technology, 6(1), 63-71.

\section{Introduction}

Developing material technology and new methodologies have provided new solutions to eliminate the drawbacks of traditional building materials. Likewise, fiber reinforced cementitious composite materials are examples of that innovations in construction materials industry. Fiber reinforcement is used mainly for preventing shrinkage related cracks and increasing energy absorption capacity of concrete. Amongst the fiber reinforced composites, Engineered Cementitious Composites, which contains cement based matrix and polyvinyl alcohol (PVA) fibers, is one of the most prominent members owing to its ductility, durability and self-healing capability. The basic idea of ECC design is to increase the low ultimate tensile strain capacity of (up to $3 \%$ ) with a pseudo ductile behavior under loading to prevent catastrophic failure of structures [1, 2]. Although initial cost of ECC production is higher compared to conventional and fiber-reinforced 
concretes, it provides higher durability, sustainability, and long term economy, especially when used at critical points of the structures [3]. Furthermore, it can heal its own cracks which are narrow with hydration of the unhydrated cementitious materials in its composition [4].

In this study, ECC is designed and produced with local wastes of Muğla region in order to achieve an economical ECC while providing an environmental solution by utilizing hazardous waste materials. In this context, fly ash obtained from Yatağan thermal power plant was used in all mixtures while quartz quarry dust was replaced with the commercial quartz sand in two of the mixtures.

\section{Fiber Reinforced Cementitious Composites}

The use of fiber-reinforced building materials dates back to ancient times when materials such as straw and horsehair were used as fibers. The first fiber-cement composite used in modern times was asbestos (a type of natural fiber) cement, which became quite common in 1900's [5-7]. Cement-based composites are generally composed of fibers embedded in a matrix consisting of cementitious powder, admixtures and aggregates. Some special materials are added mainly to increase resistance to impact loads, toughness and flexural strength [7, 8]. Type, physical properties, geometry, volume fraction and distribution of the fibers effect the composite properties to be obtained, significantly $[5,9]$. One of the most important properties provided with the use of fibers is crack control which prevents the formation of a single crack by keeping the crack faces together and help distribute the load to the matrix and improves the post-cracking ductility properties of the material. After the first crack formation, hardening is observed and the energy absorption capacity is noticeably increased with the development of multiple cracks [5]. Because of their mechanical behavior, fiber reinforced cementitious composites are used in many structural applications where very high compressive strengths are needed since values 60-120 MPa are typical and around 200-800 MPa can also be achievable by the help of low water-cement ratio, powdered material and featured chemicals [10].

\subsection{Engineered Cementitious Composites}

ECC is a type of high performance fiber reinforcement cementitious concrete (HPFRCC) which is devised by $\mathrm{Li}$ in 1993 at the University of Michigan by Li [11]. The distinctive feature of ECC is high tensile ductility and tight multiple cracking compared to conventional concrete. It shows strain-hardening behavior (Figure 1) instead of rapid failure under excessive loading. Uniaxial tensile strain capacity of ECC is 3-5\%, equivalent to 300 to 500 times more than that of ordinary concrete [12].

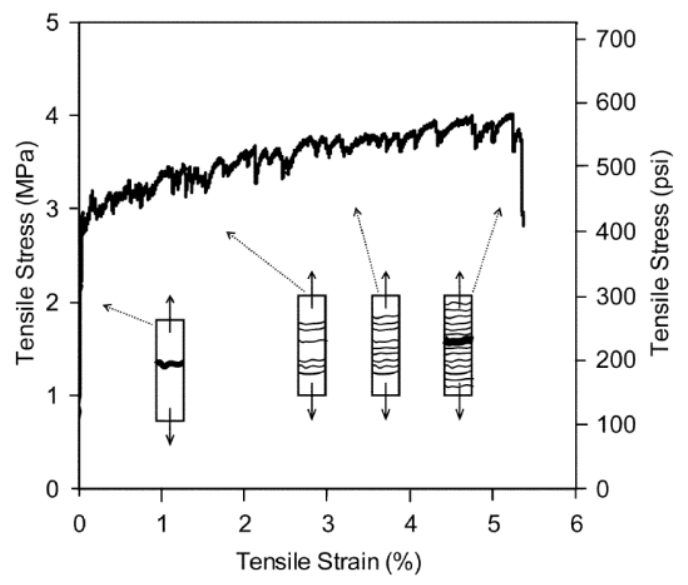

Figure 1. Strain-hardening of ECC under tensile stress [13].

PVA fiber is used in production of ECC to prevent the matrix's brittleness, providing a stronger bond with the dense matrix fibers, resulting in increased post-fracture strength. With optimum amount of PVA fiber $(2 \%$ by volume) used, the ECC attains the crack width can be limited to $60 \mu \mathrm{m}$ to $100 \mu \mathrm{m}$ [14]. Short and discontinuous PVA fibers distributed in the matrix are connected to the cement matrix with strong bonds which start to break during tensile loading and with the increase of the force, these bonds are replaced by coulomb-friction forces [11-16].

\subsubsection{Design of ECC}

The characteristics and mechanical behavior of ECC depends on the type of material used (ranging from nano-scale to mm-scale) as well as the interaction between the fiber-matrix. ECC design is based on a micromechanical design theory in which macro level performance of the composite can be attained by tailoring the singular ingredient properties. The major mechanical properties pursued by micromechanical model for ECC are strain capacity under tension and multiple crack formation in loading $[16,17]$.

ECC does not contain any coarse aggregate, since the aggregate size is very effective in creating a tighter matrix, better workability, bond between fiber and matrix and multiple crack formation [15]. Using high amount of cement yields some crucial issues such as high hydration heat, autogenous shrinkage and cost, thus high amount of fly ash is used in the composition to reduce these problems, beside it affects the mechanical properties positively [13]. ECC has a similar mixing process with normal concrete and water reducing admixtures are used in the mixtures in order to maximize workability [14].

\subsubsection{Self-Healing Properties of ECC}

Self-healing can be expressed as the capability of a material to heal itself, analogous to the healing of a wound by natural ways. If self-healing is an internal 
characteristic of the material, this self-healing type is defined as autogenous self-healing. Autogenous selfhealing can typically be observed in ordinary concrete as a result of hydration and carbonation reactions, but the crack width limits complete healing [18]. ECC exhibits self-healing properties by mutual effect of abundant cementitious materials in its composition and the controlled multiple crack formation. The crack width which are smaller than $100 \mu \mathrm{m}$ are favorable for robust self-healing while higher amounts of cementitious materials in ECC allow the formation of more hydration products [19]. The second chemical effect that causes cracks to clog is the formation of calcium carbonate by the combination of calcium ions in the concrete and carbonate ions dissolved in the water penetrated into the crack [20].

\section{Experimental Study}

\subsection{Materials}

The physical, mechanical and chemical properties of the materials used in ECC production directly affect the properties of the matrix produced. Hence, the properties of these ingredients were also determined. The chemical composition of the Portland cement, fly ash and quartz sands used in the experimental study is provided in Table 1. In addition, particle size distributions of the solid materials used in this study were determined by laser diffraction method and provided in Figure 2.

Table 1. Chemical compositions of solid materials

\begin{tabular}{ccccc}
\hline $\begin{array}{c}\text { Chemical } \\
\text { Analysis }\end{array}$ & $\begin{array}{c}\text { Portland } \\
\text { Cement } \\
\text { (\%) }\end{array}$ & $\begin{array}{c}\text { Fly } \\
\text { Ash } \\
\text { (\%) }\end{array}$ & $\begin{array}{c}\text { Quartz } \\
\text { (\%) }\end{array}$ & $\begin{array}{c}\text { Quartz } \\
\text { Quarry } \\
\text { Waste (\%) }\end{array}$ \\
\hline $\mathrm{SiO}_{2}$ & 18.69 & 50.04 & 99.37 & 91.98 \\
$\mathrm{Al}_{2} \mathrm{O}_{3}$ & 4.74 & 22.85 & 0.16 & 4.94 \\
$\mathrm{Fe}_{2} \mathrm{O}_{3}$ & 3.37 & 8.02 & 0.028 & 0.08 \\
$\mathrm{CaO}$ & 61.87 & 11.21 & 0.14 & 0.12 \\
$\mathrm{MgO}$ & 3.36 & 2.23 & - & 0.02 \\
$\mathrm{Na}_{2} \mathrm{O}$ & 0.19 & 0.27 & 0,03 & 2.77 \\
$\mathrm{~K}_{2} \mathrm{O}$ & 0.63 & 2.50 & 0,03 & 0.04 \\
$\mathrm{SO}_{3}$ & 2.93 & 0.78 & - & - \\
$\mathrm{Loss}_{\text {on }}$ & 3.62 & 7.22 & - & - \\
$\mathrm{ignition}^{2}$ & & & & \\
\hline
\end{tabular}

In the experimental study, CEM I $42.5 \mathrm{R}$ type portland cement with specific gravity of 3.15 and Blaine fineness of $3420 \mathrm{~cm}^{2} / \mathrm{g}$, conforming to European standards was used. Fly ash having a specific gravity of 2.28 and Blaine fineness of $2845 \mathrm{~cm}^{2} / \mathrm{g}$, obtained from the Yatağan Thermal Power Plant which corresponds to class $F$ according to ASTM C618-19 standard was used as secondary binder in the mixtures [21]. Polycarboxylate ether based high range water reducing admixture, conforming ASTM C494M-17 standard, was also used to enhance the workability of the of the fresh ECC mixtures during the mixing process [22].
Two different materials were used as aggregate in ECC production which are commercial quartz with particle size range of $0-200 \mu \mathrm{m}$ as named by the manufacturer and quartz quarry waste which was declared to have a size range 0-70 $\mu \mathrm{m}$. Although the particles sizes determined by laser diffraction technique as seen in Figure 2 were different than those declared by the manufacturer, nomenclature is based on the manufacturers declaration. Furthermore, in order to be certain from the potential alkali-silica reaction with quartz quarry waste, alkali reactivity test was conducted according to ASTM C1260-14 [23]. Expansions less than $0.10 \%$ were obtained indicating that the aggregate does not show deleterious reaction according to the standard.

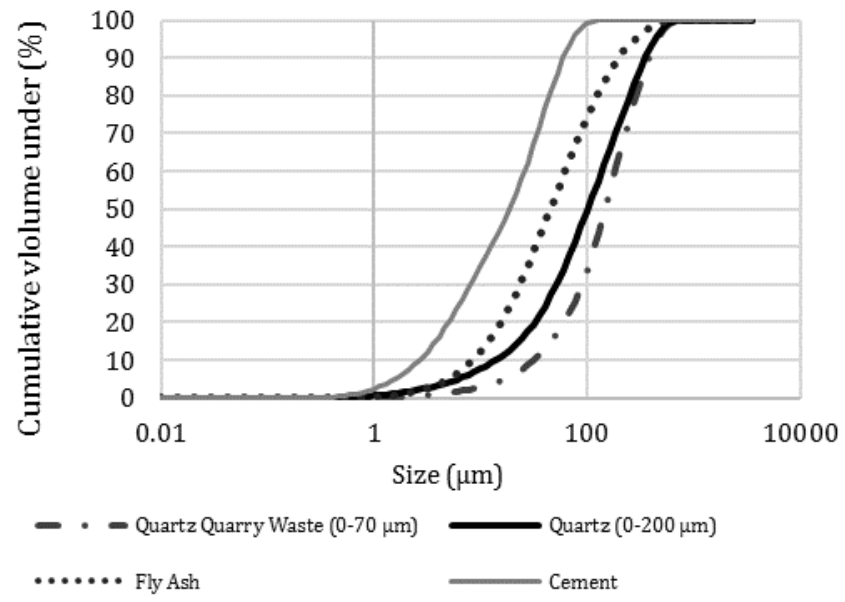

Figure 2. Particle size distributions of the materials

The properties of the PVA fibers used in ECC production as provided by the manufacturer are provided in Table 2.

\begin{tabular}{lc}
\multicolumn{2}{c}{ Table 2. Properties of PVA fibers } \\
\hline Property & Value \\
\hline Tensile strength $(\mathrm{MPa})$ & 1600 \\
Diameter $(\mu \mathrm{m})$ & 40 \\
Length $(\mathrm{mm})$ & 8 \\
Young's modulus $(\mathrm{GPa})$ & 41 \\
Elongation $(\%)$ & 6 \\
Density $\left(\mathrm{g} / \mathrm{cm}^{3}\right)$ & 1.3 \\
\hline
\end{tabular}

\subsection{Production of ECC Specimens}

In the experimental study, two control mixtures with fly ash to cement ratios of 1.2 and 2.2 were prepared. In these mixtures, besides the Portland cement, fly ash from Yatağan Thermal Power Plant and quartz sand with commercial value widely used in the ECC production were used. Then, $1.2 \mathrm{~W}$ and $2.2 \mathrm{~W}$ mixtures were produced by replacing the quartz sand used in the control mixtures with quartz quarry waste obtained from a quartz mine in Muğla. Totally four different mixtures were evaluated in the scope of the study. In the nomenclature of the mixture IDs, numbers 1.2 and 2.2 
indicate the fly ash to cement ratio, while the letter $\mathrm{W}$ indicates that quartz waste is used as aggregate as shown in Table 3. In order to determine the mechanical and the self-healing properties two different set of specimens were prepared by using these mixtures. To determine the mechanical properties, compressive strength test and 4-point bending test were performed on the first set of specimens. For the self-healing assessment, rapid chloride permeability test (RCPT), ultrasonic pulse velocity (UPV), sorptivity rate and visual inspection methods were applied on the second set of specimens. During the self-healing experiments, specimens were preloaded at 28 days up to $60 \%$ of their deformation capacities and moisture cured until the age of testing, afterwards. The remaining specimens were kept as virgin specimens and tested at the same time with the preloaded specimens. Test results obtained from preloaded and virgin specimens are compared to gain an understanding of the degree of self-healing in ECC mixtures.

Table 3. ECC mix design ratios and fresh properties

\begin{tabular}{ccccc}
\hline & $\mathbf{1 . 2}$ & $\mathbf{2 . 2}$ & $\mathbf{1 . 2 W}$ & $\mathbf{2 . 2 W}$ \\
\hline Cement & 1 & 1 & 1 & 1 \\
Fly Ash & 1.2 & 2.2 & 1.2 & 2.2 \\
Water & 0.6 & 0.864 & 0.6 & 0.864 \\
Quartz (0-200) & 0.79 & 1.152 & - & - \\
Quartz Waste & - & - & 0.79 & 1.152 \\
Plasticizer & 0.014 & 0.020 & 0.016 & 0.027 \\
Fiber (by Volume) & $\% 2$ & $\% 2$ & $\% 2$ & $\% 2$ \\
\hline $\begin{array}{c}\text { Matrix slump flow } \\
\text { (cm) }\end{array}$ & 41.8 & 41.5 & 42.0 & 42.2 \\
$\begin{array}{c}\text { ECC slump flow } \\
\text { (cm) }\end{array}$ & 12.7 & 17.8 & 20.3 & 24.5 \\
\hline
\end{tabular}

During the preparation of the mixtures, all dry materials were mixed together in a planetary type mixer. Quartz sand was first added, followed by the portland cement and the fly ash. After mixing the dry materials, the mixing water was introduced to mixture and finally water reducing admixture was added gradually until the expected consistency for the ECC was obtained. Mini slump test was used to determine the amount of admixture and to evaluate the consistency of the mixture. It was aimed to reach a spread diameter of 40 cm with mini slump test, for the mortar without fibers. The mixing process is stopped for a short time to scrape the collected materials on the inner surface and bottom of the mixer and then the mixing is continued. Finally, the mixing operation was completed after the introduction of the PVA fibers.

The basic idea of conducting a slump flow test is to determine the optimum amount of admixture to be used in the mixtures. From the previous experience, a slump flow diameter of a minimum $40 \mathrm{~cm}$ should be maintained to provide a uniform fiber distribution. However, an excessive amount of admixture may result in bleeding. The values provided herein are those needed to obtain a workable ECC. The amount of admixture in the case of high-volume fly ash can be attributed to increase in the plasticizer saturation point. Similar slump values of fresh ECC matrix may not assure similar values for ECC with fiber [24]. Nonetheless, utilization of quartz quarry dust has a positive effect on the slump of ECC which can be explained by the excess paste theory as the quartz waste particles are relatively coarser than the commercial quartz (Figure 2), it may provide a better particle packing and result in a higher amount of excess paste yielding better workability [25]. Fresh ECC mixtures were filled into pre-cleaned and oiled cylindrical molds with $20 \mathrm{~cm}$ height and $10 \mathrm{~cm}$ diameter and prismatic molds with $75 \mathrm{~mm} \times 50 \mathrm{~mm} \times$ $360 \mathrm{~mm}$ dimensions. Flexural properties were determined on the beams, while the cylinder specimens were used for rapid chloride permeability test, rate of sorptivity tests. At the end of 28 days, cylindrical specimens were cut into puck specimens with10 cm diameter and $5 \mathrm{~cm}$ height.

Immediately after casting the specimens, the molds were covered with plastic sheets for a day. 24 hours later, the specimens were demolded and placed in impermeable plastic bags along with a wet fabric. The specimens were cured at constant temperature (23 \pm $1^{\circ} \mathrm{C}$ ) for 7,28 and 90 days for mechanical tests. Specimens were removed from the bags and tested at the designated age of testing. The specimens prepared for the self-healing assessment were left in the bag for 28 days. On the $28^{\text {th }}$ day, specimens were damaged by preloading to form cracks. Both the preloaded and the virgin specimens cured under water until the test ages of $28+15,28+30,28+60$, and $28+90$ days for self-healing experiments. The number before the plus sign indicates the age of the specimens when subjected to preloading, and the number after the plus sign indicates the duration of wet curing when the self-healing test is performed.

\subsection{Determination of Mechanical Properties}

\subsubsection{Compressive Strength}

Compressive strength values of the ECC mixtures were determined as average of three specimens on cubic specimens having dimensions of $50 \mathrm{~mm} \times 50 \mathrm{~mm} \times 50$ $\mathrm{mm}$ according to ASTM C109M-16a standard at 7, 28 and 90 days [26]. Compressive strength test results are presented in Table 4.

Table 4. Compressive strength results

\begin{tabular}{cccc}
\hline \multicolumn{4}{c}{ Compressive Strength Test Results } \\
\hline Mixture & $\begin{array}{c}\mathbf{7} \text { days } \\
\text { (MPa) }\end{array}$ & $\begin{array}{c}\text { 28 days } \\
\text { (MPa) }\end{array}$ & $\begin{array}{c}\text { 90 days } \\
\text { (MPa) }\end{array}$ \\
\hline $\mathbf{1 . 2}$ & 39.3 & 63.3 & 75.2 \\
$\mathbf{2 . 2}$ & 30.9 & 51.7 & 70.3 \\
$\mathbf{1 . 2 W}$ & 40.0 & 64.9 & 78.6 \\
$\mathbf{2 . 2 W}$ & 33.8 & 61.9 & 75.1 \\
\hline
\end{tabular}

Compressive strength results revealed that the strength of the specimens produced with quartz waste are higher than those produced with commercial quartz. As expected, specimens with a fly ash to cement ratio of 1.2 
showed higher strength values than those with 2.2 as a result of rapid hydration reactions of portland cement. For the mixtures with the same fly ash to cement ratios, mixtures having higher slump values that contain waste quartz can also be regarded to have higher strength values due to better compaction and less amount of voids.

\subsubsection{Flexural Strength}

Four-point bending test was performed with deformation-controlled testing machine on beam specimens with dimensions of $360 \times 75 \times 50 \mathrm{~mm}$ in order to determine the flexural strength and deflection values. The loading rate of the universal testing machine was set to $0.3 \mathrm{~mm} / \mathrm{min}$ during loading. Three beam specimens were tested for each flexural test at 7, 28 and 90 days. Flexural strength and deflections as average of three specimens are presented in Table 5 and Table 6, respectively.

Table 5. Flexural strengths of the mixtures

\begin{tabular}{cccc}
\hline Flexural Strength (MPa) & $\mathbf{7}$ days & $\mathbf{2 8}$ days & $\mathbf{9 0}$ days \\
\hline $\mathbf{1 . 2}$ & 8.84 & 11.1 & 11.97 \\
$\mathbf{2 . 2}$ & 6.59 & 9.99 & 10.86 \\
$\mathbf{1 . 2 W}$ & 11.28 & 11.49 & 12.33 \\
$\mathbf{2 . 2 W}$ & 8.92 & 10.96 & 11.67 \\
\hline
\end{tabular}

Table 6. Deflection capacities of the mixtures

\begin{tabular}{cccc}
\hline Deflection (mm) & $\mathbf{7}$ days & $\mathbf{2 8}$ days & 90 days \\
\hline $\mathbf{1 . 2}$ & 5.16 & 3.84 & 3.32 \\
$\mathbf{2 . 2}$ & 5.64 & 5.27 & 5.16 \\
$\mathbf{1 . 2 W}$ & 5.58 & 4.88 & 3.41 \\
$\mathbf{2 . 2 W}$ & 7.87 & 6.81 & 5.68 \\
\hline
\end{tabular}

Compressive and flexural test results indicate that quartz quarry dust obtained from the region can be used successfully as an aggregate in ECC production. Similar to compressive strength test results, mixtures with quartz quarry dust namely $1.2 \mathrm{~W}$ and $2.2 \mathrm{~W}$ attained higher flexural strength values than those of 1.2 and 2.2 respectively which can again be related to the compaction and also to potential activation of fly ash by higher alkali content of quartz quarry waste [27]. When the deflection capacities of the mixtures are evaluated, it is seen that mixtures with higher amount of fly ash have higher deflection capacity due to lower matrix fracture toughness. When the mixtures with similar binder contents are compared, higher deflection capacity of the mixtures with quartz quarry dust may be attributed to more uniform fiber distribution due to better workability.

\subsection{Determination of Self-Healing Properties}

\subsubsection{Flexural Strength}

Four-point bending test was also used for the determination of self-healing properties. During the first 28 days after casting, beam specimens were placed inside plastic bags to prevent moisture lost and at the age of 28 days, they were removed from the plastic bags and preloaded to $60 \%$ of their deflection capacities.
After the preloading at 28 days, specimens were reloaded up to failure in order to assess the effect of preloading on the flexural performance of the beam specimens at the predesignated ages of testing. For each of the testing ages, three virgin (V) and three preloaded (PL) specimens were tested. After preloading at 28 days, all specimens whether virgin or preloaded, cured under water to allow self-healing to proceed until the age of testing. The test results are presented in Figure 3.

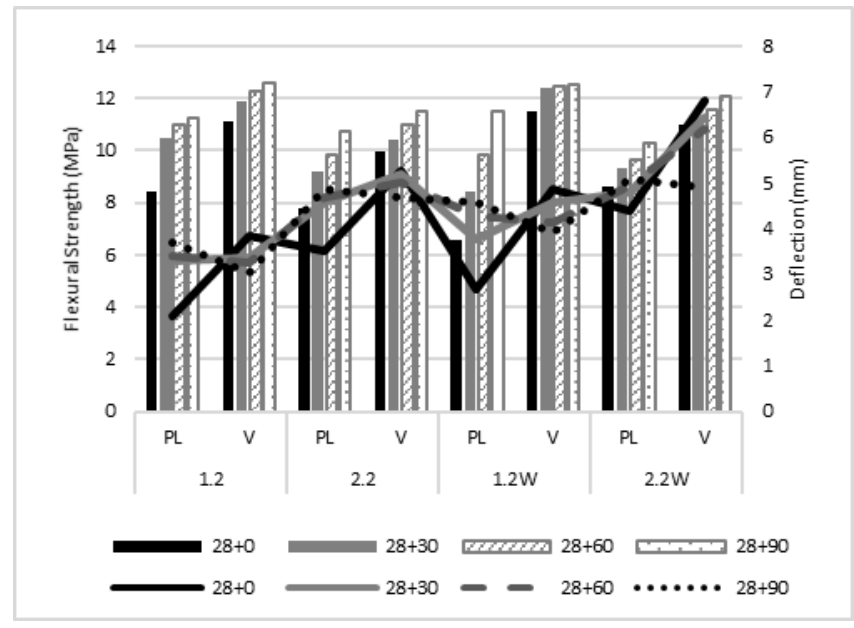

Figure 3. Flexural test results

\subsubsection{Rapid Chloride Permeability}

The Rapid Chloride Permeability Test plays an important role in the determination of the chloride permeability of concrete and therefore the estimation of its service life. Besides, it is potentially a good measure of self-healing as less amount of electrical charge is expected to pass through the concrete when the cracks are clogged. According to the ASTM C1202 standard, the concrete specimens are tested between two cell blocks filled with $\mathrm{NaOH}$ and $\mathrm{NaCl}$ solutions [28]. During the test, the current flow through the specimen under a potential of $6 \mathrm{~V}$ is monitored.

According to test results presented in Figure 4, virgin specimens produced with quartz waste resulted in higher chloride penetration compared to that of specimens containing commercial quartz. This can be attributed to the difference in the chemical composition of the aggregates as conductive ions may be extracted from the aggregate to the pore solution and increase the electrical conductivity of the cementitious material [29]. Preloaded specimens attained similar RCPT values with the virgin specimens even as early as 30 days after preloading for 2.2 and $2.2 \mathrm{~W}$ mixtures. On the other hand, the difference was apparent between the sound and preloaded specimens even at testing age of 90 days after preloading in the case of 1.2 and $1.2 \mathrm{~W}$ mixtures. This can be attributed to the high amount of unreacted fly ash particles available in 2.2 and $2.2 \mathrm{~W}$ mixtures. Furthermore, no adverse disparity is observed when quartz quarry dust is replaced with commercial quartz sand which can be considered as a positive outcome in 
terms of recycling waste quartz dust. RCPT results of the mixtures are provided in Figure 4.

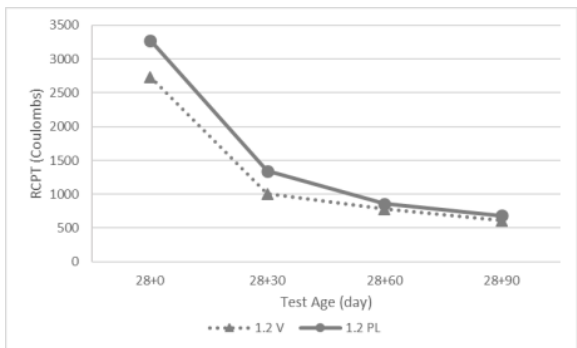

(a)

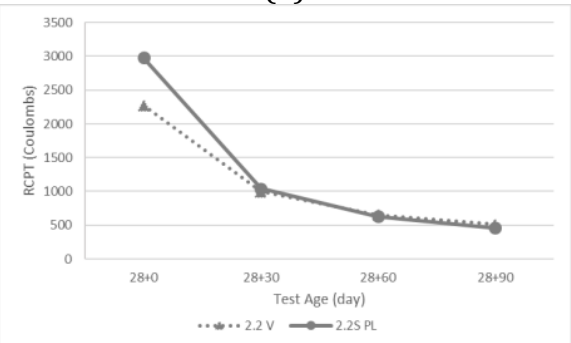

(b)

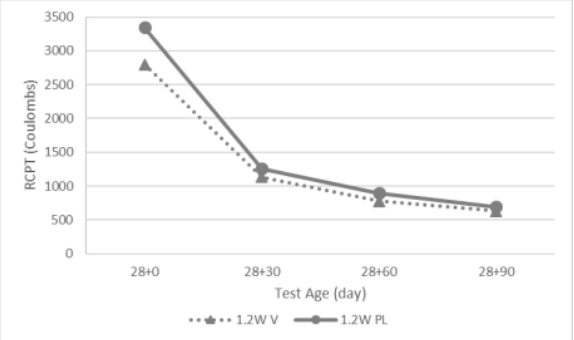

(c)

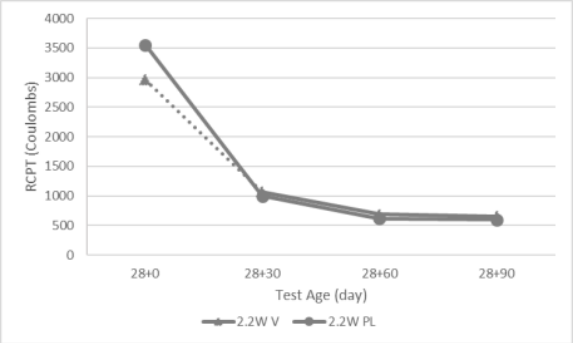

(d)

Figure 4. RCPT results

\subsubsection{Ultrasonic Pulse Velocity}

Ultrasonic pulse velocity tests were performed on beam specimens prepared for the four-point bending test. The UPV measurements were taken in accordance with ASTM C 597-16 standard using indirect transmission [30]. In the UPV test, higher velocity indicates a continuous medium while a lower velocity points out an obstacle that impairs the homogeneity of the medium such as a crack. Measurements were taken from the bottom of the specimens where the cracks are formed to force the ultrasonic pulse to transmit around the crack to track the closure in the cracks by self-healing. The results obtained from the UPV measurements are provided in Figure 5.

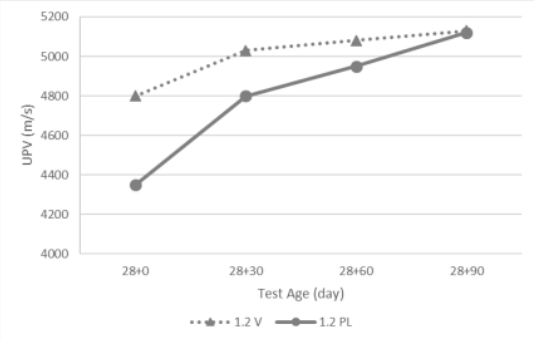

(a)

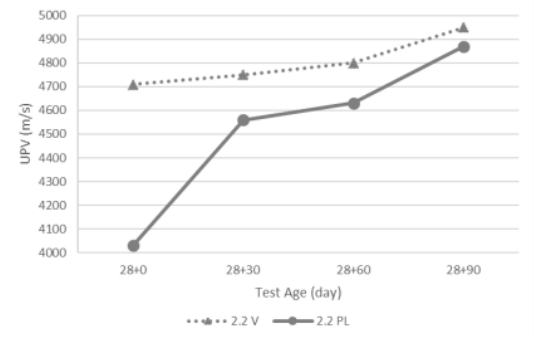

(b)

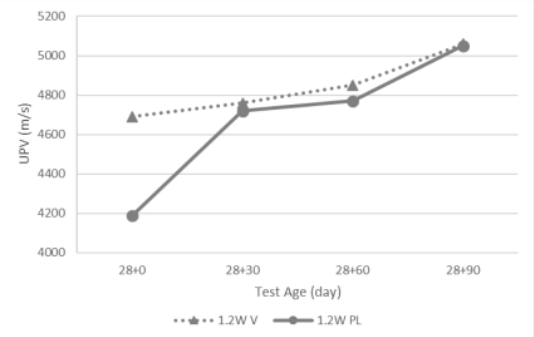

(c)

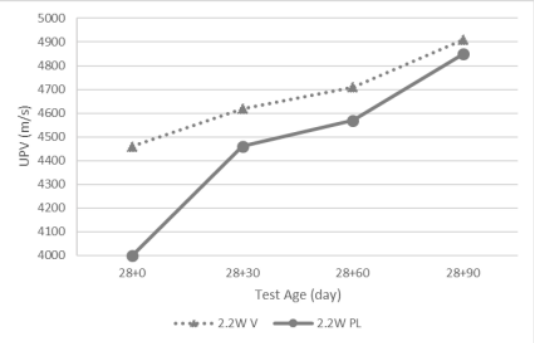

(d)

Figure 5. UPV test results

UPV values for all mixtures increased over time, indicating the closure of cracks with continued carbonation or hydration. Preloading caused a reduction in UPV values in ECC mixtures. Even so, as time passed, the difference between sound and preloaded samples almost disappeared. The convergence of the UPV values of virgin and preloaded specimens revealed that the cracks were closed over time.

\subsubsection{Sorptivity Index}

Sorptivity or absorption is a measure of the capillary porosity of a cementitious material which provides information about the transport properties. In addition, it can be used as a tool to understand the crack closure rate. The presence of cracks yields a higher sorptivity index as water penetrates more easily and faster through the specimen which gives an idea about the amount and size of the cracks. In this study sorptivity 
index was calculated similar to the procedure described in ASTM C 1585-13 standard [31]. Each index is calculated after a test period of 6 hours over two specimens and averages result are presented in Figure 6.

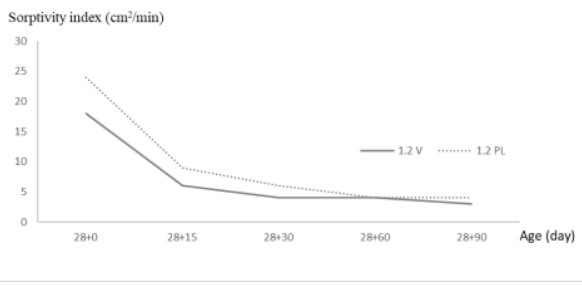

(a)

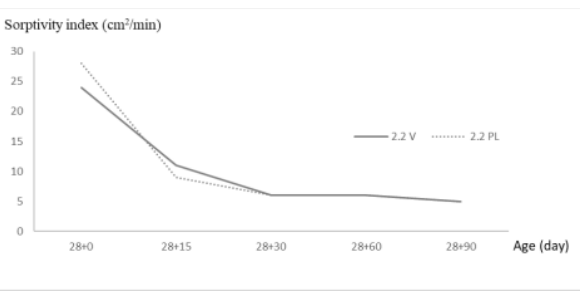

(b)

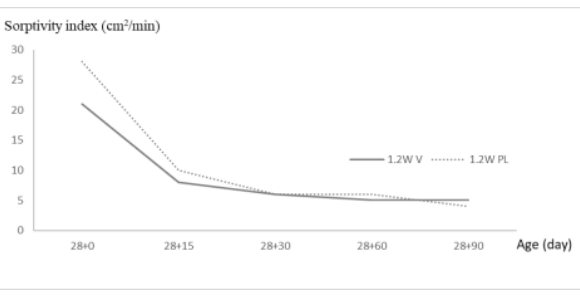

(c)

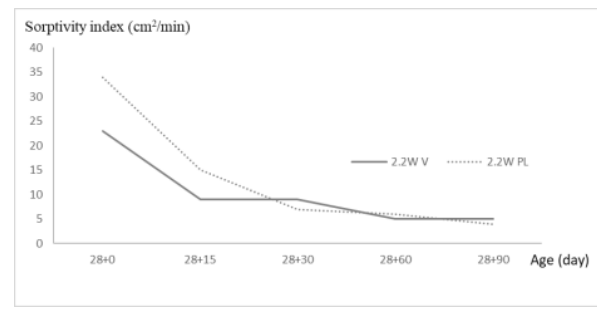

(d)

Figure 6. Sorptivity test results

Similar to the other self-healing tests, sorptivity test results also showed that all mixtures exhibited selfhealing in a similar way. Damaged specimens reached sorptivity values comparable to sound specimens earlier than $28+60$ days.

\subsubsection{Visual Inspection}

In order to follow up the self-healing processes of the damaged specimens, cracks were periodically observed visually and digital micrographs were taken periodically at $28+15,28+30,28+60$ and $28+90$ days. Crack images can be seen in Figure 8. In this figure, magnification for 1.2 and 2.2 are set to 50 times while it is 500 times for $1.2 \mathrm{~W}, 2.2 \mathrm{~W}$ mixture. As seen from the micrographs, all specimens visually closed before the end of 90 days after preloading.

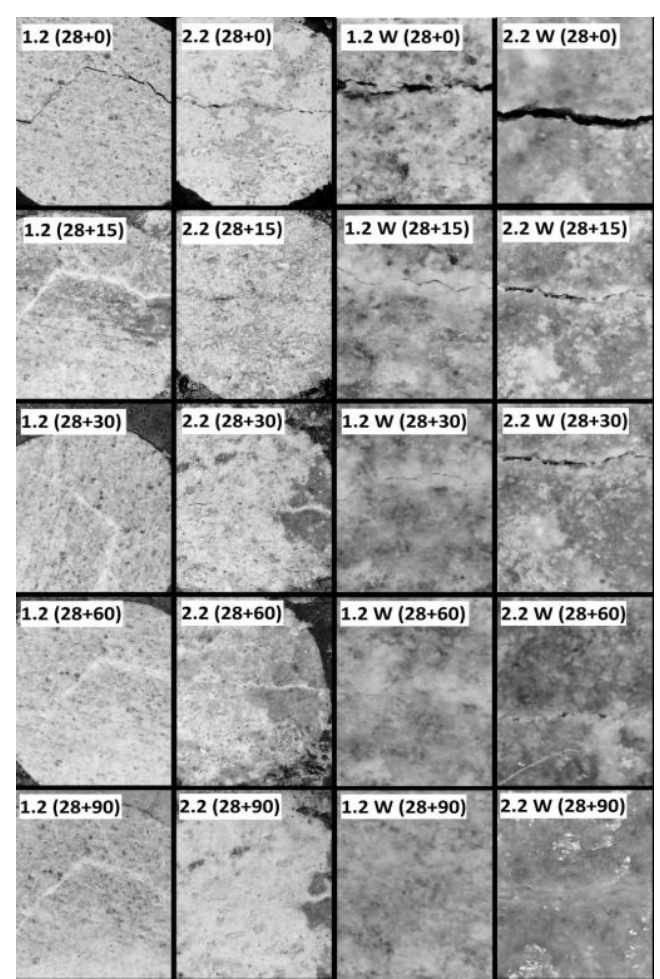

Figure 8. Crack images during the self-healing progress

\section{Conclusion}

According to the results acquired in the experimental study, fly ash obtained from Yatağan thermal power plant is employed effectively in ECC production. Mixtures with fly ash to cement ratio of 2.2 exhibited better workability compared to that of 1.2 mixture. The test results also showed that the fly ash cement ratio of the mixtures where the fly ash to cement ratio was 1.2 gives higher flexural strength values than 2.2. On the other hand, when the amount of fly ash increases, the deflection capacity of the samples under bending increases.

The results obtained from virgin and preloaded specimens in RCPT, sorptivity and UPV tests are expected to converge over time as the self-healing develops. It was revealed that the test results of preloaded specimens became closer to virgin specimens and almost all mixtures behaved similar to virgin specimens over time. This indicates that the cracks are filled with self-healing products in preloaded specimens and thus gained sufficient strength and impermeability over time as a result of continued hydration and carbonation.

The use of quartz quarry dust can be said to affect the workability positively. In addition, quartz quarry dust yielded a higher flexural strength and deflection capacity than that of commercial quartz. This can be ascribed by the particle size distribution and alkali content of the quarry waste which may activate the fly 
ash. Test results indicate that quartz quarry waste is a very appropriate material for ECC production.

\section{Acknowledgment}

This study has been granted by Muğla Sitkı Koçman University Scientific Research Project: BAP-17/006.

Authors would also like to acknowledge BASF Chemical Company, OYAK Denizli Cement Factory and Mikroman Mining Company for their material supports.

\section{References}

[1] Gohil, B.D. and Parikh K.B., "Study on Engineered Cementitious Composites with Different Fibres: A Critical Review", Int J Inno Eng Technol, vol. 6, pp. 366-370, 2016

[2] Deshpande, U.L. and Murnal P.B., "Ductile Concrete Using Engineered Cementitious Composites", Int. J. Eng. Res. Sci., vo. 5, pp. 756-760, 2016

[3] Keskin, S.B., Sahmaran, M., Yaman, I.O. and Lachemi, M., "Correlation between the viscoelastic properties and cracking potential of engineered cementitious composites", Constr Build Mater, vol. 71, pp. 375383,2014

[4] Sahmaran, M., Yildirim G. and Erdem T.K., "Selfhealing capability of cementitious composites incorporating different supplementary cementitious materials", Cem Concr Compos, vol. 35, pp. 89-101, 2013

[5] Bentur, A. and Mindess S. (Taylor \& Francis), Fiber Reinforced Cementitious Composites, New York, pg. 625,2007

[6] Mauney, M., "History of Asbestos", Date of access: 7.2.2018,https://www.asbestos.com/asbestos/hist ory/

[7] Mobasher, B. and Yu Li, C.", Mechanical properties of hybrid cement-based composites", ACI Mater J, vol. May-June, pp. 284-287, 1996

[8] Beglarigale, A. and Yazıcı, H.," Çimento Esasl Kompozzitlerde Lif matris Aderansına Kür Koşullarının Etkisinin İncelenmesi", 9. Ulusal Beton Kongresi, Antalya, pp. 517-526, 2016

[9] Brandt, A.M. (Taylor \& Francis), Cement-based Composites: Materials, Mechanical Properties and Performance, New York, pp. 39-42, 2009

[10] Khan, M.I., Abbas, Y.M. and Fares G., "Review of high and ultrahigh performance cementitious composites incorporating various combinations of fibers and ultra-fines", J King Saud Univ SciEngineering Sciences, 2017

[11] Song, G., Matrix Manipulation to Study ECC Behaviour, MSc Thesis, University of Stellenbosch, 2005

[12] Zhang, Q. and Li, V.C., "Adhesive bonding of fireresistive engineered cementitious composites (ECC) to steel", Constr Build Mater, vol. 64, pp. 431439,2014

[13] Yang, E.H., Yang, Y. and Li, V., "Use of High Volumes of Fly Ash to Improve ECC Mechanical Properties and Material Greenness", ACI Mater J, Title no. 104M68, pp. 303-311, 2007

[14] Merchant, B. and Gelot, A., "Evaluation of engineering cementitious composites (ECC) with different percentage of fibers", Int $J$ of Eng Res Technol, vol. 4, pp. 40-43, 2015

[15] Akkari, A., "Evaluation of a Polyvinyl Alcohol Fiber Reinforced Engineered Cementitious Composite for a Thin-Bonded Pavement Overlay", Minnesota Dep. of Transportation, Research Project Final Report 2011-11, 2011

[16] Li, V.C. (Ed. Nawy E), Engineered Cementitious Composites (ECC) - Material, Structural, and Durability Performance, Concrete Construction Engineering Handbook, published by CRC Press, Chapter 24, 2008

[17] Keskin, S.B., Dimensional Stability of Engineered Cementitious Composites, $\mathrm{PhD}$ Thesis, Middle East Technical University, Ankara, pg. 165, 2012

[18] Tittelboom, K. V. and Belie, N. D., "Self-Healing in Cementitious Materials - A Review", Mat, vol. 6, pp. 2182-2217, 2013

[19] Yildirim, G., Kasap Keskin, Ö., Keskin, S.B., Sahmaran M. and Lachemi M., "A review of intrinsic self-healing capability of engineered cementitious composites: Recovery of transport and mechanical properties", Constr Build Mater, vol. 101, pp. 10-21, 2015

[20] Reinhardt, H.W., Jonkers, H. K., Tittelboom, V., Snoeck, D, Belie, . N. D., Muynck, W. D., Verstraete, W., Wang, J and Mechtcherine, V., "Self-Healing Phenomena in Cement-Based Materials", RILEM, vol 11, pp. 65-117, 2013

[21] ASTM C618-19, Standard Specification for Coal Fly Ash and Raw or Calcined Natural Pozzolan for Use in Concrete, ASTM International, West Conshohocken, PA, 2019, www.astm.org

[22] ASTM C494 / C494M-17, Standard Specification for Chemical Admixtures for Concrete, ASTM International, West Conshohocken, PA, 2017, www.astm.org

[23] ASTM C1260-14, Standard Test Method for Potential Alkali Reactivity of Aggregates (MortarBar Method), ASTM International, West Conshohocken, PA, 2014, www.astm.org

[24] Yang E., Şahmaran M., Yang Y., Li V. C. "Rheological Control in Production of Engineered Cementitious Composites” ACI Mater J, vol 106, pp 357-366, 2009.

[25] Kwan A. K. H., Li L. G. "Combined effects of water film thickness and paste film thickness on rheology of mortar" Mater Str, vol. 45, pp. 1359-1374, 2012.

[26] ASTM C109 / C109M-16a, Standard Test Method for Compressive Strength of Hydraulic Cement Mortars (Using 2-in. or [50-mm] Cube Specimens), ASTM International, West Conshohocken, PA, 2016, www.astm.org

[27] Fraay, A.L.A., Bijen, J.M. and de Haan, Y.M. "The reaction of fly ash in concrete a critical 
examination" Cem Concr Res, vol.19, pp.235246,1989

[28] ASTM C1202-17a, Standard Test Method for Electrical Indication of Concrete's Ability to Resist Chloride Ion Penetration, ASTM International, West Conshohocken, PA, 2017, www.astm.org

[29] Shi C."Effect of mixing proportions of concrete on its electrical conductivity and the rapid chloride permeability test (ASTM C1202 or ASSHTO T277) results" Cem Concr Res, vol. 34, pp. 537-545, 2004.

[30] ASTM C597-16, Standard Test Method for Pulse Velocity Through Concrete, ASTM International, West Conshohocken, PA, 2016, www.astm.org

[31] ASTM C1585-13, Standard Test Method for Measurement of Rate of Absorption of Water by Hydraulic-Cement Concretes, ASTM International, West Conshohocken, PA, 2016, www.astm.org 